\title{
El Cordobazo, la Universidad, la memoria
}

\author{
Héctor Schmucler
}

Héctor Schmucler es Director de la revista Estudios

ESTUDIOS • № 4

Diciembre 1994

Centro de Estudios Avanzados de la Universidad Nacional de Córdoba
Durante el mes de mayo de este año, 1994, la revista Estudios recordó el 25 aniversario del Cordobazo. Este número da cuenta de las actividades realizadas. A veces, cuando se evocan acontecimientos históricos, acuden palabras pronunciadas sin cuidado, ruidos huecos que sólo muestran su altisonancia. No es fácil evitar estereotipos que desaniman la imaginación y provocan cansan. cio al pensamiento. Nada de ello ocurrió en el mes de mayo. Hubo algunas afirmaciones, pero muchos más fueron los interrogantes. Hubo ese sensato alejamiento de los hechos que exige el rigor del estudio, pero fueron inevitables las emociones y a veces se quebró la voz de quienes hablaron. El pudor no evitó las lágrimas. Sobre todas las cosas fue un tenaz homenaje a la memoria. Se rescataron palabras que, si no son tomadas en vano, se sitúan en las puertas de la ascesis: dignidad, fiesta, muerte.

Veinticinco es un número de años suficientemente grande como para que una parte considerable de la población tenga edades menores a esa cifra. Pero no tanto: la mayoría de los argentinos fueron testigos $\mathrm{o}$ al menos contemporáneos del Cordobazo. La recordación puso en evidencia las dificultades que la memoria encuentra para persistir. Y no por los años transcurridos. Otras fueron las distancias señaladas: la que va del entusiasmo a la indiferencia, la que separa el sentimiento de que la injusticia es insoportable de la aceptación resignada de la inequidad, la que opone convicciones sólidas que dan sentido al vivir a la dificultad de siquiera preguntarse por ese sentido.

La memoria y el olvido actúan solidariamente. El olvido es siempre ausencia de memoria en el presente. En algunos casos el olvido intenta borrar hoy lo que ayer fue vivido. 
En otros, impide la actualización de un relato. En ambas circunstancias lo que cesa es la responsabilidad de retener una palabra que, si bien menciona el pasado, actúa sobre el presente. La memoria, en este sentido, es más una guía para la conducta, una ética, que la puntual rememoración de acontecimientos. La memoria hace más que aportar datos: interpela. Recordar el pasado es, con frecuencia, el ejercicio de mirar un espejo implacable. Al lado de nuestro rostro de hoy el recuerdo sostiene otro, el que nos perteneció en el momento evocado. La imagen, entonces, puede desconcertarnos: ¿En qué medida este rostro reflejado es el mismo que aquél del recuerdo? ¿En qué sentido los nuevos rostros que nos rodean ya estaban en aquellos que la fotografia dejo fijados?

El Cordobazo - se dijo- fue una fiesta. La categoría puede resultar dificilmente asimilable a las ciencias que estudian la historia o la sociedad. Sin embargo, desde certeras consideraciones históricas, sociológicas y políticas, se reconoció que en el recuerdo de los pueblos hay actos fundantes que sólo se explican en la alegría desbordante de la fiesta. Momentos de fusión, de reconocimiento colectivo, de restitución a lo absoluto, de esperanza realizada. Como toda fiesta - se dijola del Cordobazo fue fugaz. La memoria es la encargada de renovar su fuego; el olvido vuelve lúgubre el pasado y prepara el presente para nuevos olvidos, para nuevas tristezas.

Luego - se dijo- se abrieron largos años ensombrecidos por la muerte. Si bien se ve, la idea de fiesta y la de muerte no están lejanas: ambas sustentan misterios fundantes de la existencia. Pero la muerte ignominiosa que se desencadenó en la Argentina no cabe en los registros de lo humano. La fiesta, en su plenitud, sabe que la muerte es la única certeza que comparten los hombres. Por eso la vida se vuelve responsabilidad impostergable. Esta convicción —se dijo — funda la dignidad. La dignidad, que alimenta las mejores acciones, fue el espíritu que animó toda la recordación del Cordobazo. Aunque los análisis y las interpretaciones de los hechos difirieron: para unos el Cordobazo fue el final de una historia; para otros el punto de partida.

Vivimos - también se dijo- tiempos cuya significación cuesta definir. En el aire se percibe una generalizada "voluntad de olvido". Voluntad de olvido, es decir, decisión de olvidar que suele cubrirse con argumentos atrayentes tales como la virtud de la tolerancia, la necesaria construcción de un determinado futuro, el irrenunciable avance del progreso. Se ha llegado a creer que hay un mañana tan nuevo que no admite el recuerdo del pasado. Para esa creencia pocas cosas resultan tan abominables como la nostalgia. Si sólo se trata de llegar a un horizonte que se presupone ya diseñado, no cabe otra posibilidad que buscar el camino más breve que nos lleve a él. El pasado, en estas circunstancias, puede resultar una tentación plagada de peligros. Pero - se dijo- si al presente se lo imagina como pura di- 
reccionalidad hacia el futuro, deja de existir. El presente pierde espesor. El repetido aforismo: "que los muertos entierren a los muertos", la negación radical del pasado, no percibe que los muertos habitan en los vivos. La intención de excluir el pasado sólo consigue reproducir fantasmas.

Al recordar el Cordobazo la Universidad recuperaba su sentido primigenio: ser lugar común, comunidad. Espacio donde las gentes están en compañía para saber lo que interesa a todos: universal. La Universidad, lugar del saber, también se detiene a observar las huellas, no a borrarlas. Las marcas sobre un cuerpo que pertenece a todos. Cuando "universidad" indaga su origen, su etimologia, llega al vertere latino, verter, "hacer girar", "derribar", "cambiar". La vertiente y lo que vertebra. Vértice. Desde allí, ¿cómo pensar la relación entre la Universidad y la sociedad? Si no es una afirmación meramente ocasional, ¿qué se quiere decir cuando se afirma que la universidad debe estar al servicio de la sociedad? ¿Realmente hay una sociedad que esté antes que la universidad? Siempre hay un saber sobre el que la sociedad se asienta, aunque no resulte evidente. ¿Cómo disociarlos y establecer que uno precede al otro? ¿Cómo "servirle" y a la vez instituirla? ¿Cómo ser saber de la sociedad sin ser crítica de la misma? Y más: ¿hay saber fuera de la crítica? Es posible que el servicio que la Universidad pueda prestar a la sociedad -y, por lo tanto, a sí misma - no sea otro que fortalecer sin claudicaciones su espíritu crítico. Estar en la sociedad, pero no seducida. Estar con toda la distancia necesaria como para que la lucidez, el saber, no se confunda con melodías tranquilizadoras de la época. La universidad como memoria actuante. Como anamnesis: camino al saber a través de la memoria. Como advertencia: otra vez el verter de la etimología. La vertiente que labra el camino en la roca, el rastro donde se reconoce aquello que hizo lo que somos.

La Universidad --dijimos- es, o debería ser, lugar de permanente reflexión sobre la vida material y espiritual de la sociedad. Dábamos razones para que las jornadas recordatorias del Cordobazo se llevaran a cabo: el saber como riesgo, la Universidad también en el papel de antena sensible al devenir de la sociedad, a lo que está siendo y que, consecuentemente, no puede percibirse como un corpus acabado en el que los acontecimientos puedan detenerse con frío reposo. $\mathrm{Si}$ se pretende ejercer la responsabilidad que entraña el pensar, es necesario, a veces, transitar por caminos menos sólidos, senderos no imaginados de antemano. Afrontar el peligro del extravío momentáneo, aceptar la angustia de ese momento en que los hechos no se doblegan ante nuestros esquemas, superar el cansancio de recomenzar una y otra vez. Pensar, seguramente, no es un proceso algorítmico; no existe una matriz de indicaciones cuya correcta aplicación nos lleva a la verdad. Ante una realidad no siempre domeñable, suelen languidecer las metodologías rigurosas. 
El Cordobazo -cualquiera sea la interpretación que se realice de él-constituye un hecho decisivo en lo que ocurrió en la Argentina durante el último cuarto de siglo. Esta razón es suficiente como para justificar su análisis. Hay otra, indisociable del espacio de la ética. Despojados de su memoria, los pueblos se opacan, mueren. Y suelen morir en medio de la algarabía de imaginar que el pasado no interesa, aturdidos por voces que los llaman a no recordar, apalabrados por ilusionistas que susurran que hoy, en cada hoy, todo empieza de nuevo. Las raíces pueden secarse si una voluntad de memoria no se opone a la voluntad de olvido. Sin esta fidelidad no hay ética perdurable. Recordarlo tal vez constituya el deber prioritario de la Universidad. 